\title{
Rare vascular complication of acute meningococcal meningitis in a child
}

\author{
Indar Kumar Sharawat, Vignesh Subramani, Shivan Kesavan, Lokesh Saini
}

Department of Pediatrics, Post Graduate Institute of Medical Education and Research, Chandigarh, Punjab, India

\section{Correspondence to} Dr Lokesh Saini, drlokeshsaini@gmail.com

Accepted 7 September 2018

\section{DESCRIPTION}

A 5 -year-old boy presented with fever for 4 days and acute-onset weakness of the right upper and lower limb for 1 day. There was no history of headache, seizures, vomiting and altered sensorium, rash or bleeding from any site. On examination, he had normal mentation, neck stiffness, Kernig's sign, right-sided upper motor neuron facial palsy and right hemiparesis. The rest of the systemic examination was unremarkable. A clinical diagnosis of acute meningitis with left Middle Cerebral Artery (MCA) territory stroke was made.

Cerebrospinal fluid examination revealed 980 cells $/ \mu \mathrm{L}$ (90\% polymorphonuclear leucocytes and $10 \%$ lymphocytes), glucose $47 \mathrm{mg} / \mathrm{dL}$, proteins $110 \mathrm{mg} / \mathrm{dL}$ and Neisseria meningitides antigen was positive; however, no organism could be isolated on microscopy and culture. He was unimmunised for meningococcal vaccine. Blood culture was sterile. Detailed stroke and immune deficiency work-up was negative. MRI of the brain showed altered signal changes in left frontal lobe, anterior limb of the internal capsule, left caudate head and putamen (figure 1). MR angiography of intracranial vessels revealed attenuated left middle cerebral artery flow voids (figure 2). The child was started on intravenous ceftriaxone and oral aspirin in antithrombotic doses. At 6 months follow-up, he was asymptomatic and had no weakness.

Bacterial meningitis is a serious infection of central nervous system and $N$ meningitides is one of the the most common aetiologies. Focal neurological deficit is seen in 5\%-14\% patients, and it results from vasculitis, transient vasospasm and septic thrombosis of intracranial arteries, cortical veins and dural venous sinuses, leading to the infarction of cerebral territories. ${ }^{1}$ Vascular involvement in meningococcal meningitis secondary to vasospasm resulting from

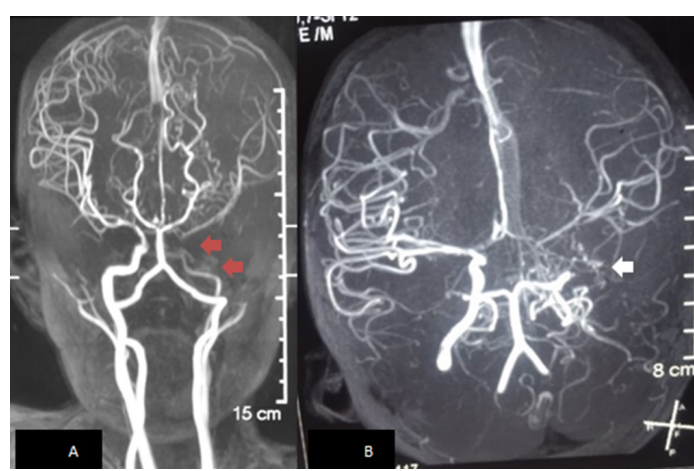

Figure 2 MR angiography of cerebral vessels. (A) Timeof-flight MR angiography shows attenuated cervical, petrous, cavernous and supraclinoid portion of left internal carotid artery (arrow). (B) Left middle cerebral artery and its branches are markedly attenuated with marked paucity of cortical branches and formation of collateral vessels (arrow). A1 segment of left anterior cerebral artery was also attenuated.

subarachnoid inflammation or vasculitis is rarely described in children; however, there are anecdotal reports in adults. ${ }^{2}$ The radiological findings in index patients were suggestive of secondary vasculopathy pattern and it may be secondary to the underlying meningococcal meningitis. Post-meningitis vascular events usually present within the first week of illness and are commonly seen with Streptococcus pneumoniae, $N$ meningitides, Haemophilus influenzae and Mycobacterium tuberculosis. ${ }^{3}$ The treatment of vasculopathy includes oral aspirin in antithrombotic doses and heparin may be more effective in recurrent strokes or infarction. To conclude, acute-onset focal neurological deficit in a child with acute bacterial meningitis should raise a suspicion of cerebral vasculopathy.

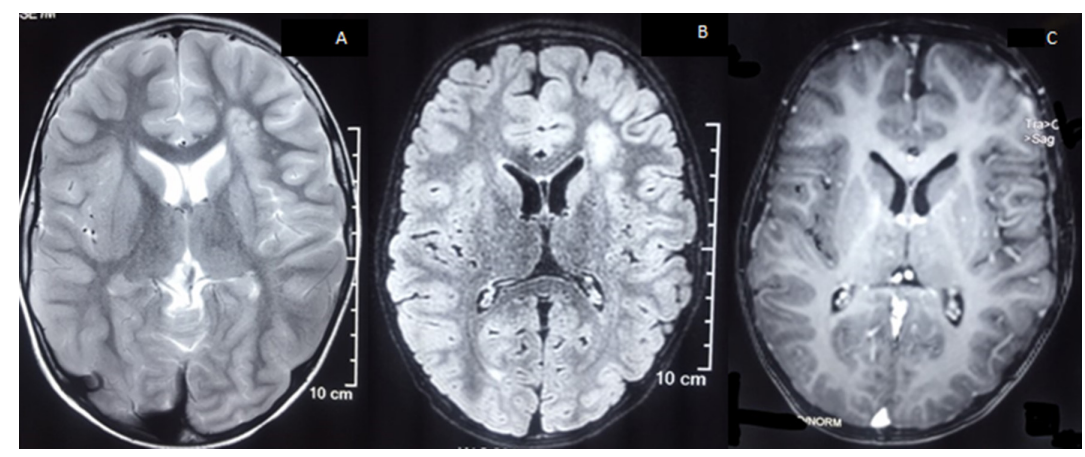

Figure $1 \mathrm{MRI}$ of the brain. (A) T2-weighted and (B) fluid-attenuated inversion recovery axial scans showing subacute infarct involving left frontal cortex, anterior limb of internal capsule, left caudate head and putamen. (C) T1-weighted post-gadolinium axial images showing patchy contrast enhancement. 


\section{Learning points}

- Bacterial meningitis is a serious infection of central nervous system and Neisseria meningitides is one of the most common underlying aetiology.

- Post-meningitis vascular events are rare and usually present within the first week of illness and are commonly seen with Streptococcus pneumoniae.

- The treatment of vasculopathy includes oral aspirin in antithrombotic doses and heparin may be more effective in recurrent strokes or infarction.

Contributors IKS: patient management, analysis of radiological data, literature review and initial draft manuscript preparation. VS and SK: patient management, literature review and initial draft manuscript preparation. LS: clinician-in-charge, critical review of manuscript for important intellectual content and final approval of the version to be published.

Funding The authors have not declared a specific grant for this research from any funding agency in the public, commercial or not-for-profit sectors.

Competing interests None declared.

Patient consent Parental/guardian consent obtained.

Provenance and peer review Not commissioned; externally peer reviewed.

\section{REFERENCES}

1 Pathan N, Faust SN, Levin M. Pathophysiology of meningococcal meningitis and septicaemia. Arch Dis Child 2003;88:601-7.

2 Hsu SS, Kim HS. Meningococcal meningitis presenting as stroke in an afebrile adult. Ann Emerg Med 1998;32:620-3.

3 Czartoski T, Hallam D, Lacy JM, et al. Postinfectious vasculopathy with evolution to moyamoya syndrome. J Neurol Neurosurg Psychiatry 2005;76:256-9.

Copyright 2018 BMJ Publishing Group. All rights reserved. For permission to reuse any of this content visit http://group.bmj.com/group/rights-licensing/permissions.

BMJ Case Report Fellows may re-use this article for personal use and teaching without any further permission.

Become a Fellow of BMJ Case Reports today and you can:

- Submit as many cases as you like

- Enjoy fast sympathetic peer review and rapid publication of accepted articles

- Access all the published articles

Re-use any of the published material for personal use and teaching without further permission

For information on Institutional Fellowships contact consortiasales@bmjgroup.com

Visit casereports.bmj.com for more articles like this and to become a Fellow 